\title{
THE EXISTING ROLES OF LITERACY TEACHERS IN THE ERA OF MULTILITERACIES: A SOCIOCULTURAL PERSPECTIVES
}

\author{
Rama Dwika Herdiawan \\ English Language Education Program, Universitas Majalengka \\ ramadwika@unma.ac.id
}

\begin{abstract}
Literacy is defined traditonally as 'the ability to read and write' and it is also regarded as the ability to understand every single iinformation in different contexts or fields. Nevertheless, the new literacy approach in the point of view of the poststructuralism covers the representation of texts in context, different values, meanings and the principles of multiliteracies. Traditional and modern concepts of literacy have correlation with a number of sociocultural activities which occurs in the in the society as well as the classroom which represents a social space. This study focuses on explaining the term literacy and multiliteracies in the postmodern world and also the existing roles of literacy teachers for the practical activities in Indonesian literacy classrooms.
\end{abstract}

Keywords: Literacy Teachers, Multiliteracies, Sociocultural Perspectives

\section{Introduction}

In terms of sociocultural perspectives, literacy embraces different notions of reading and writing which are related to the notions of speaking and reading (Gee, 1996, 2000; New London Group, 1996). The definition of literacy has been shifted from the ability to read and write to the ability to understand several of information in different context. As a result, the sociocultural approach to literacy education brings the learners to learn different coverage of literacy learning based on the different context of situation and culture (Alvermann \& Mac Lean, 2007). The new literacies are concerned with new methods of thinking, valuing, and practicing in the instructional process. In addition, the use of digital technology contains the forms of hypertexts in which the learners understand them outside and inside the classroom as the new forms of social practices. In the theoretical lens of multiliteracies, classroom is considered as the social circumstance which covers several entities which need to be identified and also understood from a myriad of point of views (Leander \& Zacher, 2007). Therefore, the learners are required to deal with the cognition of their belief, values, and identities in the classroom particularly in learning literacy. Kern (Cited in Herdiawan, R.D, 2020), who states "literacy focuses on reading and writing in the learners' social practices which mostly shape the ability of reading and writing as the main requirements of written discourse rather than different coverage of linguistic and cognition. Based on the condition, the teachers should implement their roles which reflect the aspect of culture as well as social to guide and educate the learners professionally.

\section{Research Methoodology}

This study employs theoretical review in which the researcher or author synthesizes a number of relevant researches on the existing roles of literacy teachers in the era of multiliteracies from the latest sources. The theoretical reviews represents the guiding parameter to figure out the better understanding towards the concept of the existing roles of literacy teachers in the era of multiliteracies year by year. In case of the introduction, the roles have been theoretically employed by considering sociocultural aspects in the multiliteraces context . In 
addition, the scholars' reviews result in new schemata in connection with constructing knowledge and skills in the existing roles of literacy teachers in the era of multiliteracies. This study is aimed to reveal what the conceptual and practical sides of the existing roles of literacy teachers in the era of multiliteracies that contribute to the improvement of learning literacies material.

\section{Findings and Discussion}

\subsection{Teacher as co-inquirer}

In terms of members of social practices in the classroom, students are educated to enhance a practical thought where they are capable of comprehending how social practices are established via a number of actions and words. This enables them better figure out the relationships, identities and values in the society (Beach \& Myers, 2001). From Beach and Myers' point of views, teacher-student engagement in the content-focused curriculum is regarded as an expert-novice engagement. In the student-centered, the curriculum teacher is take a role as an expert who guide the students and the students is the one who explore the teachers' knowledge as well as the given instructional activities. However, a practical curriculum, with the proper content of multiliteracies, the teacher and the student are considered as co-inquirers, that facilitate both of them with "social and symbolic interaction" (Beach \& Myers, 2001). This role is similar to the notion of being a broder-crosser that is concerned with the development of developing their potency from traditional culture into the new culture (new literacies in the era of multiliteracies) (Giroux, 1992).

\subsection{Teacher as mediator}

Teacher has a typical role in which he/she is responsible for providing the students real learning experience. Dewey (1963), the teacher' responsibility is to assist learners construct a useful educational experience. Teacher takes a role to transmit the knowledge as well as facilitate the students during the instructional process. A teacher's role is also to mediate the knowledge in which he or she takes a part in improving the lack of pragmatic knowledge (Mason, 2000, p. 346). In case of Vygotskian psychology (Vygotsky, 1978), the analysis of Zone of Proximal Development (ZPD) is very crucial to comprehending the other roles for the purpose of problem solving. This zone focuses on the zone where the children have interactions with the social environment and the teacher creates the learning system for them (Moll, 1990). In brief, teachers must have sufficient knowledge to interact with the students and they could become mediators in the social practices by considering what they have particularly for teaching purposes.

\subsection{Teacher as intellectual}

Teacher is required to have the intellectuality in transferring the proper knowledge to the sudents. It is in line with Giroux (1988) who claims, that teachers must be intellectual instead of taking a role as implementers of running the instructional programs. Therefore, teacher is required to possess a strong passion in resisting against the programs which he/she considers useless and in acting out the instruction to the contexts of teaching and learning process. Teachers and students must be able to implement their efforts to be democratic societies, and actualize their critical thinking in order to develop themselves and decide policymaking. Freire and Macedo (1987) define this role as teacher as initiator of change.

2.4. Teacher as liberator

In this role, the teacher has a capacity to liberate as well as control everything in the instructional process to embody the effectiveness of student-teacher interaction. The differing point between mediation and intervention (Goodman \& Goodman, 1990) represents the literacy teacher's another role as liberator. When the teachers have intervention, they act out as the controller of things and the determiner of social conventions. It is also in relation to Freire (1970) who states, that the teacher trasnfers the knowledge into the students' heads. In contrast, in the liberal model, students should be trained as well as guided so that they are able to predict their literacy development as a dimension of liberation and to question the 
social reality around them.

\subsection{Teacher as kid watcher}

The teacher should be able to monitor the mobility of the students during the instructional process but they are not able to construct the zone of proximal development for the students. It is also connected with Goodman and Goodman (1990), who declares, that literacy teachers cannot create zones of proximal development for students. Nevertheless, they are able to notice their students to figure out what they have to do with some assistances. A successful teacher is capable of establishing proper zones in order that students will construct better use of opportunities for learning. In addition, Gee (1996) states that teacher need to attentive to student's in terms of on-going practical activities and direct to the appropriate aspects of experience within the culture so that their students are able to expand their models of home culture and school culture.

2.6. Teacher as researcher

Being a researcher could become the main elements that must be well-implemented by the teachers. Cochran-Smith and Lytle (1999) differentiate three approaches to developing knowledge in the teacher education: knowledge for practice, knowledge in practice and knowledge of practice. The first one, knowledge for practice, focuses on the content knowledge that is usable for the teachers in teaching places. The second one, knowledge in practice, is concerned with how teachers learn through their practices, narratives and reflection. The third one, knowledge of practice, represents knowledge teachers need that is collected through systematic inquiry in communities of practice and this knowledge can be employed by the teacher himself, by the immediate teacher community and finally by the larger community of educators (Cochran-Smith \& Lytle, 1993). This researcher role of teachers contributes to an ongoing practice-research-practice chain in the classroom.

\section{Conclusion}

Meaning in context is affected by the existing social practices where the students and teachers have close interaction. Gee (2000) claims that meaning is negotiated by experiences of learners and situated meanings assist students "recognize and act on the world in specific ways" (Gee, 2000). Therefore, literacy is defined as reconstructing those situated meanings in Discourses (forms of being in the world, identity kits), not about an ability to read and write. Literacy teachers, therefore, is required to their students be capable to make meanings in different Discourses. In Indonesia, Most of people tend to employ a classical definition of literacy and hardly consider about multiliteracies and its pedagogical implications. The constructivist and student-centered curriculum point out literacy as an individual reality instead of a social one. In spite of the current education revolution, the teachers still use measuring tools and the relevant rubrics to evaluate the growth mindset of their students. The teacher and students' experiences are a combination of knowledge-centered and studentcentered practices. Teachers possess the power to make decision about activities and practices. Intellectual and liberal teachers are required in our classrooms in order that students are able to easily make meanings in developing their languag. Teachers who are able to mediate, carry out research and inquire will give better environments for their students. Therefore, sociocultural perspectives in teaching and learning need be declared into Indonesian education settings and the existing roles of new literacies' teachers need more attention.

\section{References}

Alvermann, D.E., \& McLean, C.A. (2007). The nature of literacies. In L.S. Rush, A.J. Eakle, $\&$ A. Berger (Eds.), Secondary school literacy: What research reveals for classroom practice (pp. 1-20). Urbana, IL: National Council of Teachers 
of English.

Beach, R., \& Myers, J. (2001). Inquiry-based English instruction: Engaging students in life and literature. New York: Teachers College Press. Cochran-Smith, M., \& Lytle, S.L. (1993). Inside/outside: Teacher research and knowledge. New York: Teachers College.

Cochran-Smith, M., \& Lytle, S.L. (1999). Relationships of knowledge and practice: Teacher learning in communities. In Review of research in education (Vol. 24, pp. 249-306). Washington, DC: American Educational Research Association.

Dewey, J. (1963). Experience and education. New York: Macmillan Publishing. Freire, P. (1970). Pedagogy of the oppressed. New York: Seabury.

Freire, P., \& Macedo, D. (1987). Literacy: Reading the word and the world. Westport, CT: Bergin \& Garvey Publishers.

Gee, J.P. (1996). Social linguistics and literacies: Ideology in discourses (2nd ed.).London: Taylor \& Francis.

Gee, J.P. (2000). Discourse and sociocultural studies in reading. In M.L. Kamil, P.B. Mosenthal, P.D. Pearson, \& R. Barr (Eds.), Handbook of reading research (Vol. 3, pp. 195-207). Manwah, NJ: Lawrence Erlbaum Associates.

Giroux, H.A. (1988). Teachers as intellectuals: Toward a critical padagogy of learning. Granby, MA: Bergin \& Garvey Publishers.

Giroux, H.A. (1992). Border-crossings: Cultural workers and the politics of education. New York: Routledge.

Goodman, Y.M., \& Goodman, K.S. (1990). Vygotsky in a whole-language perspective. L.C. Moll (Ed.), Vygotsky and education (pp. 223-250). Cambridge: Cambridge University Press.

Herdiawan, R. D., Saleh, M., \& Warsono, D. S. (2020, February). School Literacy Improvement Efforts in a State Junior High School. In 3rd International Conference on Learning Innovation and Quality Education (ICLIQE 2019) (pp. 543-551). Atlantis Press. 